\title{
Hisztiretorika
}

\author{
Lózsi Tamás \\ ELTE Tanitó- és Óvóképző Kar Magyar Nyelvi és Irodalmi Tanszék
}

\begin{abstract}
Absztrakt
Jelen tanulmány Berg Judit Hisztimesék (2005) című kötetében szereplő öt írás közül három, közvetlenül a témához kapcsolódó, azaz tényleges „hisztimese” retorikai elemzése, amely elsősorban a meggyőzésre koncentrál. A tanulmányban megfogalmazott kutatási kérdés: Milyen retorikai eszközöket használnak, hogyan érvelnek ezek a mesék a kisgyermekek meggyözése érdekében A tanulmány célja rámutatni a retorika interdiszciplinaritására olyan, a mindennapos nevelési és/vagy pedagógiai gyakorlatban is jól használható példák segítségével, melyekben a gyermekirodalmi művekben (is) felbukkanó meggyőzési módszerek, érvelési technikák kerülnek bemutatásra.
\end{abstract}

Kulcsszavak: kortárs gyermekirodalom, retorikai elemzés, meggyőzés és érvelési technikák

\section{Retorika mindenhol}

\section{A retorika természete}

A retorika egyik legkorábbi meghatározása Platóntól származik, aki szerint az a lelkek irányítása beszédek révén (Platón, 2004). További ókori meghatározások: „a retorika olyan képesség, amely minden egyes tárgyban feltárja a meggyőzés lehetőségeit” (Arisztotelész,1999. p. 1355), „a retorika a jól beszélés tudománya" (Quintilianus, 2009, p. 34).

A 20. századi és a napjainkat jellemző felfogás Quintilianus tágabb meghatározásához kapcsolódik, e szerint a retorika az a tudományág, amely a diskurzus müködésével foglalkozik, legyen az írott vagy beszélt. A diskurzus célja pedig informálni, meggyőzni vagy motiválni egy hallgatóságot, amely lehet egy ember vagy emberek csoportja is (Corbett \& Connors, 1999, p. 1). Wacha Imre (2000, p. 54) megfogalmazásában a retorika a) müfajismeret, b) a meggyőző nyilvános beszéd, c) a prózai ékesszólás, a választékos stílus tana és d) szerkesztéstan.

Douglas Ehninger (1968) esszéjében a retorika három történelmi korszakát különíti el: a klasszikus periódust, a késői 18. századot, és a modern retorikát. Meghatározása szerint a retorika egy szervezett, konzisztens és koherens módja a gyakorlati diskurzus vizsgálatának. 
A klasszikus retorika alapvetően grammatikai természetű és pedagógiai orientációjú volt, mivel leírta a beszéd nyelvtanát, elkülönítve a részeit és feltárva ezek kapcsolatát. A klasszikus szerzők megkülönböztették a retorika módszereit a grammatikától vagy a logikától, másrészt felfedezték a retorika politikai és etikai összefüggéseit. Elvégezték a beszéd részein kívül a szónok feladatainak, a beszédfajtáknak, a bizonyítékok típusainak, a stílus jellegzetességeinek a felosztását. Emellett olyan mintákba rendezték ezt a nyelvtant, amely lehetővé tette azok oktatását.

A 18. századi brit „új retorika” pszichológiai természetű, mivel a beszéd és a hallgató elméje közötti kapcsolatra helyezte a hangsúlyt. Napjaink retorikája pedig szociológiai természetü, mivel úgy tekint a retorikára mint a megértés és az emberi kapcsolatok fejlesztésének eszközére.

Ha visszatekintünk a platóni meghatározásra, azt látjuk, hogy már ott elörevetíti a pszichológiai és szociológiai (sőt szociálpszichológiai) nézőpontot: „a lelkek irányítása beszédek révén”. Az arisztotelészi definícióból szintén következik, hogy ahol emberek meggyőzése szóba kerül, ott a retorika is szerepet kap. A 20. század egyik legeredetibb retorikai gondolkodója, Kenneth Burke ezt így fogalmazta meg: „Ahol meggyőzés van, ott retorika is, és ahol szöveg (jelentés) van, ott meggyőzés is van (1966, p. 305)."

A retorika és a szociálpszichológia erős kapcsolata nyilvánvaló, de emellett a retorikának köze van a nyelvészethez, a nyelvműveléshez, az igazságszolgáltatáshoz és a természettudományokhoz (legalábbis a tudománykommunikációhoz), a pedagógiához és a média tanulmányozásához is (vö. Pölcz, 2020).

\section{A retorika területei}

A klasszikus retorika a szónok (az író, a szövegalkotó; az üzenet feladója) öt feladatát különíti el :

1. a feltalálás (inventio),

2. az elrendezés (dispositio),

3. a kidolgozás vagy stílus (elocutio),

4. az emlékezetbe vésés (memoria)

5. az előadásmód (pronuntiatio, actio).

A fejezet egészéhez használt és ajánlott szakirodalmak: Adamikné, 2013; Adamik \& A. Jászó \& Aczél, 2004; Barthes, 1997; Corbett \& Connors, 1999; Plett, 1988, 2000, 2001.

A szöveg (bármilyen szöveg, sőt bármilyen kommunikációs aktus) műfajairól és szerkezetéről a retorikai tanítás az első. A beszédfajok tana a kiinduló pontja a szövegtípusok és műfajok elkülönítésének. Az alábbi összefoglaló táblázat a beszédfajok ókori rendszerét mutatja (Arisztotelész, 1999; Knape 2000, p. 36-37). Láthatjuk, hogy a mai sajtó, illetve média szövegfajtái ugyanúgy visszavezethetők erre a három beszédfajra, akár az irodalmi műfajok. 
1. táblázat

A mai sajtó és média müfajai és a beszédfajok

\begin{tabular}{|l|l|l|l|}
\hline \multicolumn{1}{|c|}{ Beszédfaj } & \multicolumn{1}{c|}{ Célja } & \multicolumn{1}{c|}{ Ideje } & \multicolumn{1}{c|}{ Érvei } \\
\hline Tanácsadó & rábeszélés/lebeszélés & jövő & hasznos/káros \\
\hline Törvényszéki & vádbeszéd/védőbeszéd & múlt & jogos/jogtalan \\
\hline Bemutató & dicséret/feddés & jelen & szép/rút \\
\hline
\end{tabular}

Az általános iskolában fogalmazásórákon az elsők között tanuljuk meg, hogy egy jó szövegnek három főbb része van: a bevezetés, a tárgyalás és a befejezés. Ezt a felismerést, illetve a szövegszerkezet általános jellegzetességeit szintén a retorika vizsgálódásainak köszönhetjük. Ez a szónok második feladata: a dispositio, vagyis az elrendezés. A beszéd részeiről először Korax gondolkodott, tőle származik a bevezetés - tárgyalás - befejezés hármas felosztás, amelyhez Teisziasz hozzákapcsolta negyedik beszédrészként a bizonyítást. Arisztotelész (1414) a tételt és a bizonyítást tekintette egy beszéd kötelező részeinek, az összes rész pedig így alakult nála: bevezetés, tétel, bizonyítás (ennek része a cáfolás), befejezés. Cornificius $(2011$, p. 1) hat beszédrészt különít el: bevezetés, elbeszélés, tétel, bizonyítás, cáfolás, befejezés. Quintilianus Szónoklattanában (2009) hozzátesz egy hetedik részt is, a kitérést, amely bárhol előfordulhat a beszédben. Azt is láthatjuk, hogy a szerkesztett szövegek alkotói a mai napig tartják magukat a retorika által lefektetett szabályokhoz, s ezért az irodalmi, a tudományos és a sajtó szövegei felépítésükben a hat-, illetve hétrészes sémát, de legalább a hármas tagolást követik, amely tetten érhető akár a Verdi-operaáriákban vagy a James Bondfilmekben is. Természetesen nem minden szövegben kötelező az összes résznek benne lennie, $\mathrm{s}$ a sorrendjük sem szigorúan kötött.

A feltalálás nemcsak az anyaggyüjtést jelenti, hanem az érvelés megtervezését is. Ahogy az elrendezés vonatkozik az érvek rendjének a kialakítására is. Már az ókorban Arisztotelész (1999), majd Quintilianus kétféle bizonyítékot különböztet meg az érvelés során: külső és belső bizonyítékokat. A retorikán kívüli bizonyítékok a beszédtől függetlenül léteznek, ilyenek a törvények, az elöítéletek, a pletykák, a szerződések, a tanúk, az eskük, a statisztika. A retorikán belüli bizonyítékokat a szónok hozza létre a beszéd során, ezek adódhatnak a beszélő személyéből, szándékából (éthosz), az általa kiváltott hatásból (pathosz), illetve magából az üzenetből, a logikából (logosz).

A logikai érvek lehetnek deduktívak vagy induktívak. A logikában a deduktív bizonyítás a szillogizmusok (kategorikus, hipotetikus, diszjunktív) használatával történik. A szillogizmusban mindig három kijelentés van: a nagyobb premissza, a kisebb premissza és az ezekből következő konklúzió. A szillogizmusban a premisszák igazságából következik a konklúzió igazsága, s ezeknek minden esetben igaznak kell lenniük, hogy logikailag helyes legyen 
a következtetés. A mindennapi életben, így a retorikában azonban általában nem használhatunk százszázalékos igazságokat a meggyőzésben, hiszen érvelésre akkor van szükség, ha véleménykülönbség áll fenn.

A retorikai dedukció az enthüméma. Egyrészről az enthüméma premiszszái nem feltétlenül igazak, csak valószínűek. Másrészt az enthüméma legtöbbször csonka a szillogizmushoz képest: kimondatlanul marad vagy az egyik premissza, vagy a konklúzió. A görög en thümo kifejezés jelentése: ami a gondolatban van. Az enthümémát tehát a hallgatóságnak kell kiegészítenie, miáltal a hallgatóság is bevonódik az érvelésbe.

A retorikai indukció a példa. A logikában akkor járunk el helyesen az indukció során, ha az összes esetet felsoroljuk, s azokból általánosítunk. A hétköznapi érvelésben azonban egy-egy jól megválasztott példa meggyőző ereje sokszor nagyobb. A példa mindig a hasonlóságon alapul, lehet kitalált vagy megtörtént eset.

Az etikus és patetikus érvek inkább az érzelmekre hatnak, a hétköznapi meggyőzés folyamatában nagyon nagy szerepük van. A beszélő éthosza tulajdonképpen a hitelessége, az, hogy mennyire lehet hinni neki. Az éthoszt is a beszéddel lehet létrehozni, például ha azt mutatjuk, hogy magunk is hiszünk abban, amiről szeretnénk meggyőzni a hallgatóságot. A pathosz kifejezetten a hallgatóság érzelmeinek felkorbácsolását jelenti, például amikor egy ügyvéd szánalmat akar ébreszteni a bíróban a védence irányában („,csak az éhség vette rá a lopásra”), vagy az orvos félelmet kelt („ha nem változtat az életmódján, rövidesen meghal").

A szónok harmadik feladata a kifejezésmód vagy stílus (elocutio) kidolgozása. A stílus az illőség erényére épül: a megfelelő szavaknak és mondatoknak a feltalálása (Quintilianus, 2009). Quintilianus megfogalmazásában a stílus feladata a dolgokat, érveket odavinni a hallgatóhoz. Ez a gondolat nagyon hasonló Perelman (1977/2018) jelenlét-teóriájához: a stílus segítségével tudjuk a dolgokat jelenlévővé tenni befogadók számára, s ez az érvelés alapja.

\section{A hiszti, az irodalom és a retorika}

A hiszti szó a hisztériából keletkezett elvonással, illetve az elvonás kicsinyítő képzővel történő továbbképzésével. Eredeti jelentésben „nagyfokú ingerlékenységben, indulatos kitörésekben, szorongásban (...) megnyilvánuló idegállapot, betegség" (ÉKsz²., p. 524). Speciálisan a dackorszakban bekövetkező indulatkitöréseket szokás hisztinek nevezni, amely a kisgyermek fejlődésének természetes velejárója (vö. Vida, 2011).

A hiszti vagy dacreakció a kisgyermek önállóvá válásának, az én-élménynek, a saját akaratnak a megnyilvánulása. Az én-élmény gyakorlása során óhatatlanul bekövetkező frusztrációs feszültségből ered (Mérei \& V. Binét, 1970/1997). Erikson (1997, p. 33-34) szerint az autonómia szakaszába a kisgyermeket sebesen kifejlődő teljesítményei, mint a mozgás, a beszéd és a megkülönböztetés képessége juttatják el, ugyanakkor megtapasztalja a moz- 
gástér határait is; a korszak pszichoszociális konfliktusa az autonómia vagy szégyen, illetve kétség között húzódik.

A hiszti közvetlen kiváltó oka legtöbbször a gyermek és a felnőtt akaratának ütközése, amikor a gyereket önállóságában korlátozzák, illetve amikor egy számára érthetetlen cselekedetre parancsolják (Fazakas, 2014).

A dacreakció, a hiszti kezelésére több különféle módszert javasolnak a szülőknek szóló tanácsadó írások. Ezek között rendre szerepelnek a következők, illetve ezek kombinációja: kiemelni a gyermeket az adott helyzetből, elterelni a figyelmét (tágítani a kontextust), humort alkalmazni (Deliága \& Lovász, 2017).

Mindhárom említett módszert segíti a mese, a megfelelő gyermekirodalom. Sokszor a "gyere, elmondok/olvasok neked egy mesét” önmagában elterelheti a gyermek figyelmét a hisztit kiváltó vágyról, a mesemondás/meseolvasás helyzetének megteremtése pedig kiemeli abból a helyzetből, amelyben a hiszti keletkezett. Ha pedig a mese (vagy éppen vers) úgy szól róla és a hisztiről, hogy közben egyszerre megnevetteti és megnyugtatja, az igazán csodás eredmény.

A mese katalizátorként müködik a gyermek érzelmi intelligenciájának fejlesztésében. A mese megtestesíti a gyermek lelkivilágát. A negatív szereplők pedig éppen megfelelőek arra, hogy a kisgyermek beléjük vetíthesse a megzabolázhatatlan indulatait. „Egy jó mese komolyan veszi a nehézségeket, nem ad tanácsot, nem oktat ki, hanem szimbolikus úton nyújt megoldást a gyermek problémáira úgy, hogy az érzelmi fejlettségének szintjén fejti ki a hatását, megmozgatva a gyermek képzeletét és érzelmeit, segítve őt a félelmei és vágyai megszelídítésében" (Kádár, 2013, p. 56).

Kádár Annamária (2014) a Mesepszichológia 2. című kötetében témák szerint válogatott meseajánló is van. A témák egyike a hiszti és a dackorszak.

Az irodalom, amit kisgyermekkorban alapvetően a mese képvisel, tehát szerepet játszik a dackitörések „kezelésében”. A retorika olyannyira az európai kultúra integráns része (az iskolai oktatást évszázadokig meghatározó septem artes liberales egyike), hogy az irodalmi műveket szándékosan vagy akaratlanul a retorikai szabályok szerint hozták létre. Ha egy művet legalább részben retorikai szabályok szerint hoztak létre, akkor a retorika ismerete segít a megértésében is (Adamikné, 2009).

A mese nem csak gyönyörködtetni akar, hanem nevelni/tanítani is. A nevelés pedig nem más, mint meggyőzés. A meggyőzés pedig a retorika kompetenciája (vö. Lózsi, 2020).

Természetesen az irodalom nem közvetlen érvelés, a kisgyermekeknek szóló mese különösen nem a logikai érvek felsorakoztatásával győzi meg az befogadóját, hanem érzelmek kiváltásával.

Arisztotelész (1999) szerint „döntés végett van a retorika” és „az érzelmek azok a tényezők, melyek megváltoztatják az emberek ítéleteit”.

Quintilianus (2009) rögzíti az érzelmek felkeltésének eljárásait. Az egyik eljárás a deinószisz (nagyítás, túlzás), amely korábban nem létező érzelmet 
kelt a döntéshozóban (jelen esetben a befogadóban), vagy a meglévő érzelmeit felnagyítja. A másik eljárás a phantaszia (képzelet), melynek segítségével a távol lévő dolgok képmásai úgy jelennek meg, mintha jelen lennének és a szemünkkel látnánk őket (vö. Perelman jelenlévőségfogalmával).

Külön ír a nevetésről, nevettetésről, amely megszünteti a bíróban (itt a mese hallgatójában) a nyomasztó érzéseket, oldhatja a feszült figyelmet, vagy kizökkentheti a fásultságból (Quintilianus, 2009).

\section{Anyag és módszer}

Jelen elemzés anyaga Berg Judit Hisztimesék (Ecovit Kiadó Kft., Budapest, 2005/2013) címü kötetében szereplő mesék. A kötetben öt írás található, amelyek közül három kapcsolódik közvetlenül a témánkhoz, azaz tényleges "hisztimese": a Hiszti manó, A csupasz kislány és a Rendrakós mese.

A vizsgálat módja a retorikai elemzés, amely elsősorban a meggyőzésre koncentrál. A kutatási kérdés: Milyen retorikai eszközöket használnak, hogyan érvelnek ezek a mesék a kisgyermekek meggyőzése érdekében?

A retorikai kritika is elsősorban a szövegre összpontosít, de figyelembe veszi a szerzőt és a közönséget is, a művet a szerző és a befogadók közötti kommunikáció hordozójának tekinti. A szerzőre vonatkozó benyomásokat is a szövegből gyưjti össze (vö. az éthosz mint a szónok jelleme, ahogyan az a beszédben megnyilvánul), azt a magatartást akarja kideríteni, amelyet a szerző azért hozott létre a szövegben, hogy hatást gyakoroljon a befogadóra. Az irodalomtudományban lényegében retorikai alapú a hermeneutika explication de texte (szövegmagyarázat) módszere, valamint a lehetséges hatást (is) vizsgáló reader response irányzat. A retorikai elemzés alkalmas mindenféle szöveg vizsgálatára a reklámokon, dalszövegeken át a meséig (Corbett, 1969; Lózsi, 2012, 2020; Tóth, 2020).

A retorikai elemzés szempontsora lényegében követi a szónok feladatait, amelyek meghatározzák a retorika rendszerét, tehát tulajdonképpen hat fö szempontot különíthetünk el (Adamikné, 2012; Cooper, 1989), melyek a következők:

- A retorikai szituáció megállapítása.

- A müfaj (beszédfaj) meghatározása.

- A szerkezet feltárása.

- Az érvelés vizsgálata.

- A stílus vizsgálata.

- Az előadásmód vizsgálata.

Természetesen az elemzés sajátos szempontjai, valamint az elemzett szöveg jellege alapján egyes szempontok hangsúlyosabbak lehetnek, mások akár ki is hagyhatók. Jelen esetben a meséknek a „hisztikezelésben” betöltött szerepére, a befogadó kisgyermekek meggyőzésének eszközeire koncentrálok az elemzés folyamán. 


\section{Az elemzés eredményei}

\section{A retorikai szituáció}

A retorikai szituáció „személyek, események, tárgyak, viszonyok szövevénye, és az a kényszer, amely határozottan megnyilatkozásra késztet" (Bitzer, 1968, p. 1-2). A retorikai szituáció fö összetevői a szükséglet, a hallgatóság és kényszer (Bitzer, 1968).

A mesemondás és mesehallgatás vagy meseolvasás szituációjában a személyek a mesemondó (a narrátor) és a hallgató vagy olvasó, bár a 2-4 éves gyerekeknek szóló mesék esetében hallgató. Természetesen az elsődleges „szónok” a szerző, s a mesét egy gyermeknek felolvasó felnőtt először befogadó, aki a saját értelmezését is közvetíti a felolvasás során. A szituációkban viszont a felolvasó jelenik meg szónokként, a partikuláris hallgatóság pedig az(ok) a kisgyermek(ek), aki(k)nek előadja a mesét.

A szónokot (írót, a mesemondót, előadót) az a szükséglet készteti megszólalásra, hogy valamilyen hiányosságot vél felfedezni, amelyet a beszéd segítségével képes kijavítani. A hisztimesék esetében ez a szükséglet, a dackorszakát élő gyermek viselkedése, illetve maga az aktuális dackitörés, a hiszti. Berg Judit, a Hisztimesék szerzője maga beszélte el, hogy a saját gyermeke megnyugtatására találta ki ezeket a meséket (lásd a Felnőttmese: Egy nagyon hisztis pici lányról címü írást a kötetben). A szerzőt mesemondásra késztető szükségletet ebben az esetben ismerjük. Feltehetően hasonló szükséglet készteti a mesék felolvasására a dackorszakukat élő gyermekek szüleit is (saját tapasztalatom is ez).

A harmadik „szónok” a mese belső narrátorra, aki nem azonos a mese alkotójával, s természetesen a konkrét előadóval sem. Retorikai szempontból ennek a szövegben lévő „szónoknak” a szándékait (és éthoszát) tudjuk vizsgálni, bár azok valószínűleg nem különböznek jelentősen a szerző, illetve a fizikai mesemondó szándékaitól.

A Hiszti manó című mese bevezetése tulajdonképpen a szükséglet leírása: „Volt egyszer egy Zsófi nevü kislány. Nagyon szeretett hisztizni. Mindenre azt mondta: nem akarom, és még kiabált is hozzá."

A csupasz kislány című történet egy kislányról szól, aki egy nap nem akart felöltözni, hanem egész nap meztelenül szerette volna a szokásos életét élni, például a játszótérre menni. Ez ismét egy tipikusnak tekinthető „hisztihelyzet": a gyermek nem tartja magát a konvenciókhoz, lázad. A Rendrakós mese egy újabb általános helyzetet mutat be: a föszereplő gyermek nem akarja elraknia játékait. A mesék belső szituációjában és a mesélés helyzetében is hasonló szükségletet vesz észre a szónok: fel kell oldani a felnőtt és a gyermek akarata közötti feszültséget, el kell érni például, hogy a gyermek felöltözzön vagy segítsen rendet rakni.

A retorikai szituáció elméletében a hallgatóság (vagy ahogyan a mai meggyőző kommunikációban hívják a célcsoport) azokból áll, akik befolyásolha- 
tók a beszéddel és képesek döntést hozni az ügyben. A hisztimesék esetben a dacoló/hisztiző kisgyermek az, akit a szónok (a meseolvasó szülő) szeretne befolyásolni, s végső soron ő az, aki döntést hoz: abbahagyja a hisztit, s magáévá teszi (interiorizálja) a szülői akaratot.

A retorikai szituáció harmadik összetevője a kényszer vagy korlát minden olyan megszorítás, (személyek, események, tárgyak és kapcsolatok), amelyek részei a helyzetnek, és hatalmukban áll korlátozni a beszélőt a szükséglet felismerésében, módosításában. A korlátok két fő osztálya megegyezik a bizonyítékok két fó típusával: vannak olyanok, amelyek a megnyilatkozótól és az ő módszereitől függnek (Arisztotelész (1999): művészeten belüli bizonyítékok), illetve vannak, amelyeket a szónok csak felhasználhat (művészeten kívüli bizonyítékok; Bitzer, 1968). A mesék belső világában részletesen kidolgozott korlátokkal találkozunk: ezek azok az elemek, amelyek előreviszik a cselekményt (akár a szereplők jelleme, a segítő vagy éppen hátráltató elemek). A meseolvasás, -mondás szituációjában a legfőbb korlátot a valós és a mesebeli helyzet hasonlósága és különbsége jelenti.

\section{A müfaj}

A retorikai beszédfajok közül a mesét mint az egyik legősibb irodalmi műfajt leginkább a bemutató beszédhez tartozónak vélhetnénk, hiszen bemutat egy történetet, hogy a jelenben gyönyörködtesse a hallgatóságát. Ugyanakkor a meséknek általában, s a vizsgált hisztimeséknek különösen nem csak a gyönyörködtetés a célja, hanem a hallgatóság jövőbeli viselkedésének a befolyásolása is, ezért ilyen szempontból tanácsadó beszédnek tekinthetjük.

A mese epikus műfaja a fentieken kívül még kétféleképpen kapcsolódik a retorikához: 1. az elbeszélés az egyik beszédrész, amely bizonyító erővel bír; 2. a mese mint (kitalált) példa, az érvelés eszköze. Az utóbbival kapcsolatban fontos megjegyeznünk, hogy a példabeszéd, példázat műfaja a meggyőzésért jött létre. A hisztimesék valójában a a dackitörések kezelésére megalkotott példázatok (vö. Lózsi, 2020).

\section{A szerkezet}

Ahogy fentebb már láthattuk, a retorika a beszédrészek tanával alapozta meg a szövegek szerkezeti elemzését, illetve ebből származik a szövegalkotás tanulásakor elsajátított hagyományos szerkezet is. A szónoki beszéd részei a bevezetés, az elbeszélés, a tétel és felosztása, a bizonyítás, a cáfolás, valamint a befejezés, esetleg a kitérés. A 20. századi szerzők erre építették megállapításaikat: Kenneth Burke (1931/1968) öt típusát határozta meg a szerkezeti formáknak (szillogisztikus haladás, kvalitatív haladás, konvencionális forma, ismétlődő forma, alkalmi vagy kisebb formák), Cooper (1989,) pedig a szöveg szerkezetének három szintjét különítette el (nagy, közepes és kis struktúrák). A három megközelítés összefüggését a 2. táblázat mutatja. 
2. táblázat

Szerkezeti típusok

\begin{tabular}{|l|l|l|l|}
\hline \multicolumn{1}{|c|}{ klasszikus: } & a beszéd fó részei & $\begin{array}{c}\text { az elrendezés logi- } \\
\text { kája: időrend, } \\
\text { ok-okozat stb. }\end{array}$ & $\begin{array}{l}\text { alakzatok, fordulatok, } \\
\text { érvek, párbeszédek } \\
\text { fordulói }\end{array}$ \\
\hline Burke (1931/1968): & $\begin{array}{l}\text { szillogisztikus } \\
\text { haladás }\end{array}$ & $\begin{array}{l}\text { konvencionális for- } \\
\text { mák }\end{array}$ & $\begin{array}{l}\text { alkalmi vagy kisebb } \\
\text { formák }\end{array}$ \\
\hline Cooper (1989): & nagy struktúrák & közepes struktúrák & kis struktúrák \\
\hline
\end{tabular}

A hagyományos beszédrészek elsősorban a törvényszéki beszédre alapoztak, amelyből az elbeszélés az eset ismertetését jelentette. A mese önmagában elbeszélés, természetesen belső szerkezettel. Bevezetés, elbeszélés (fö rész, avagy tárgyalás) és a befejezés biztosan van minden mesében, így a három elemzett hisztimesében is. Példaként mindhárom mese egészében a bizonyítás része (különösen ha azokat a nevelési helyzeteket vesszük figyelembe, amelyekben valószínűleg elhangzik vagy utalás történik rá), de emellett a belső szerkezetükben is található bizonyítás, illetve cáfolás.

A szerkezetnek (ahogy a stílusnak is) nagy szerepe van a meggyőzésben. A mesék szerkezetét az időrend mellett az ok-okozati elrendezés is jellemzi, így mindhárom mese egy-egy érv. Általános szerkezetük így ragadható meg: 1. a főszereplő gyermek ellenszegül a szülőnek vagy az általános konvenciónak, azaz dacol, hisztizik, 2. az ellenszegülésből valamilyen negatív hatás következik, 3. a negatív következmény megszüntetése érdekében a gyermek abbahagyja a dacolást. A szerkezet és az érvelés szempontjából is fontos, hogy a negatív hatás nem a szülőtől származó büntetés, hanem magának a hisztinek a (természetesen mesei) következménye. Nézzük a három mese szerkezetét ebből a szempontból. (3. táblázat) 
3. táblázat

A mesék szerkezete

\begin{tabular}{|l|l|l|l|}
\hline & \multicolumn{1}{|c|}{ Hiszti } & Negatív következmény & \multicolumn{1}{c|}{ Megoldás } \\
\hline $\begin{array}{l}\text { Hiszti } \\
\text { manó }\end{array}$ & $\begin{array}{l}\text { Zsófi hisztizik, nem } \\
\text { akar hazamenni, regge- } \\
\text { lizni stb. }\end{array}$ & $\begin{array}{l}\text { Megjelenik Hiszti } \\
\text { manó, kineveti és a } \\
\text { barátjának nevezi. }\end{array}$ & $\begin{array}{l}\text { Zsófinak nem tetszik } \\
\text { Hiszti manó, ezért nem } \\
\text { hisztizik többet. }\end{array}$ \\
\hline $\begin{array}{l}\text { A csupasz } \\
\text { kislány }\end{array}$ & $\begin{array}{l}\text { Kati nem öltözik fel, } \\
\text { hanem egész nap mez- } \\
\text { telen marad. }\end{array}$ & $\begin{array}{l}\text { A meztelensége miatt } \\
\text { nem tud kimenni a } \\
\text { barátaihoz játszani (a } \\
\text { gyerekek nem hívják). }\end{array}$ & $\begin{array}{l}\text { Végül mégis felöltözik, } \\
\text { a gyerekek örömmel fo- } \\
\text { gadják a homokozóban. }\end{array}$ \\
\hline $\begin{array}{l}\text { Rendrakós } \\
\text { mese }\end{array}$ & $\begin{array}{l}\text { Peti nem akar rendet } \\
\text { rakni vacsora után. }\end{array}$ & $\begin{array}{l}\text { A játékai sorban el- } \\
\text { hagyják, mert úgy érzik, } \\
\text { nincs helyük Peti szo- } \\
\text { bájában. }\end{array}$ & $\begin{array}{l}\text { A véletlenül ott maradt } \\
\text { mackót Peti a helyére } \\
\text { teszi, ezért visszatérnek } \\
\text { a játékok, Peti rendben } \\
\text { el is pakolja öket. }\end{array}$ \\
\hline
\end{tabular}

A mesékben a tétel a mese tanulsága. A kortárs mesékben nincs didaktikusan kimondva a tanulság, hanem vagy a befejezésben jelenik meg, vagy implicit marad.

A Hiszti manó című mese befejezése az alábbiakban fogalmazódik meg: „És Zsófi soha többé nem hisztizett, mert nem szerette volna, hogy visszajöjjön Hiszti manó, és újra kinevesse őt." A tételt szimbolikusan, ugyanakkor a gyermekek számára érthetően és elfogadhatóan közvetíti ez a befejezés: a hisztiző gyerek nevetséges. Nagyon fontos motívum, hogy nem a szülő neveti ki a gyereket, hanem egy mesebeli lény, akire a felelősséget is át lehet hárítani hisztiért (összhangban a kisgyermek mágikus gondolkodásával).

A csupasz kislány meséjében a címszereplő barátai mondják ki a tételt, természetesen nem általános megállapításként, hanem a konkrét helyzetre vonatkozóan: „Előbb öltözz fel, mert ruha nélkül nem jöhetsz ki a ház elé!”

A Rendrakós mese tétele (tanulsága) teljesen implicit, a teljes történet ismeretében fogalmazhatjuk meg.

A részben vagy teljesen implicit tétel rokonságot mutat az enthümémával, ezáltal a meggyőzés eszköze, mivel a gyermeknek magának kell levonni a tanulságot a mesékből, saját magát győzheti meg, s nem szülői parancsra cselekszik.

\section{Az érvelés és a stílus}

Ahogy eddig is láthattuk, az érvelés a meggyőző szövegek minden szintjét áthatja, $\mathrm{s}$ végső soron minden nyelvi megnyilvánulásban feltételezhetjük a meggyőzésre irányuló szándékot (vö. az idézett burke-i megállapítást).

A stílus maga is a meggyőzést szolgálja, egyrészt felkelti és ébren tartja a hallgatóság figyelmét, másrészt segíti a jelenlévőség megteremtését. Jelen 
mesék hallgatóságát a dackorszakukat élő két-három éves kisgyermekek, így a mesék stílusa is hozzájuk alkalmazkodik. A stílusnemek (egyszerü, középső, fennkölt) közül leginkább a középsőhöz sorolhatnánk: alapvetően a mai magyar köznyelvet használja, de előfordulnak benne a müfajhoz kötődő fordulatok („Volt egyszer...), ritkább szavak (selyembugyogó, csengettyüs), a hallgatóság életkorához kapcsolódó szavak, kifejezésmódok (mamája, lábacskáim, toporzékol, kikukucskál). Mivel jelen elemzés célja elsősorban a meggyőzés vizsgálata, önmagában a stílust nem elemzem részletesebben.

A jelenlét fogalma Perelman (1977/2018) érveléselméletének fontos eleme: a szónok azáltal irányíthatja a hallgatóság figyelmét, hogy bizonyos elemeket tudatosan tesz jelenlévővé és jelentőssé. A jelenlétet megteremtheti egy tárgy bemutatása, vagy az előadás technikája, azaz a stíluseszközök megfelelő használata. Az egyik technika az amplifikáció, amely jelentőssé tételt jelent, ezt ismétléssel, a részletek halmozásával, bizonyos részek hangsúlyozásával, alakzatokkal és szóképekkel érik el. A másik eljárás pedig a hypotyposis vagy szemléletesség, amely úgy ábrázolja a dolgokat, mintha a szemünk előtt lennének.

A hisztimeséket hallgató kisgyermek olyan események, helyzetek elbeszélésével találkozik, amelyek a saját életében is gyakran megeshetnek. Az, hogy róla (is) szól a mese egyrészt jelentőssé teszi a mesében leírt helyzetet és a felkínált megoldást, másrészt segíti a mese föszereplőjével való azonosulást, amely azonosulás szintén hozzájárul a meggyőzéshez.

A szemléletesség persze müfaji sajátosság is, ugyanakkor az azonosulást és a meggyőzést is szolgálja. A Hiszti manó címü történet második mondatából megtudjuk, hogy a fószereplő Zsófi nevü kislány „nagyon szeretett hisztizni”, majd ezt az állítást szemléletes példák követik (amelyek közül több ismerős lehet a mese hallgatójának is). A csupasz kislány címszereplőjét háromszor hívják a gyerekek, s ő háromszor nem tud velük menni a meztelensége miatt. Ebben fokozást is megfigyelhetünk, mivel egyre kívánatosabb a kislány számára, hogy a gyerekekkel menjen. A Rendrakós mesében részletesen megismerhetjük, hogyan hagyták el Petit a játékai: először a kisautó, aztán a kockák, majd a bohóc, a dömper, a kisvonat, a labda, végül a mesekönyv. Ezek a részletezések megfelelnek annak, amit a szónoki beszédben a tétel felosztásának hívunk. Ez a tétel természetesen nem ugyanaz, amiről meggyőzni kívánja a hallgatóságot az elbeszélő (a kimondott vagy implicit tanulság), hanem egyfajta témamegjelölés.

A fentebb már említett stíluseszközök, mint a gyermeknyelvi szavak használata szintén a jelenlét és az azonosulás létrehozását segítik elő.

A meggyőzéshez a szónok használhat külső és belső érveket, a belső érvelés történhet ésszel (logosz), erkölccsel (éthosz) és érzelmek keltésével (pathosz). Mivel az érvelőnek tekintettel kell lennie a hallgatóságára, amely jelen esetben 2-3 éves kisgyermekekből áll, a logikai érvelés haszna kérdéses. Ezzel együtt ezek a mesék nem nélkülözik a kvázilogikai érveket. Tulajdonképpen mindhárom mese története visszavezethető egy-egy hipotetikus szillogizmusra, illetve enthümémára. (4. táblázat) 
4. táblázat

Mesei szillogizmusok

\begin{tabular}{|l|l|l|l|}
\hline & \multicolumn{1}{|c|}{ Premissza 1. } & \multicolumn{1}{c|}{ Premissza 2. } & \multicolumn{1}{c|}{ Konklúzió } \\
\hline $\begin{array}{l}\text { Hiszti } \\
\text { manó }\end{array}$ & $\begin{array}{l}\text { Ha valaki folyton hiszti- } \\
\text { zik, nevetséges lesz. }\end{array}$ & $\begin{array}{l}\text { Zsófi nem akarta, hogy } \\
\text { kinevessék. }\end{array}$ & $\begin{array}{l}\text { Zsófi abbahagyta a } \\
\text { hisztizést. }\end{array}$ \\
\hline $\begin{array}{l}\text { A csupasz } \\
\text { kislány }\end{array}$ & $\begin{array}{l}\text { Ha valaki ki akar menni a } \\
\text { lakásból, fel kell öltöznie. }\end{array}$ & $\begin{array}{l}\text { Kati ki akart menni } \\
\text { játszani. }\end{array}$ & Kati felöltözött. \\
\hline $\begin{array}{l}\text { Rendrakós } \\
\text { mese }\end{array}$ & $\begin{array}{l}\text { Ha egy gyermek sze- } \\
\text { retné, hogy a játékai } \\
\text { meglegyenek, el kell } \\
\text { pakolnia öket. }\end{array}$ & $\begin{array}{l}\text { Peti meg akarta tartani } \\
\text { a játékait. }\end{array}$ & $\begin{array}{l}\text { Ezért végül helyére tette } \\
\text { őket. }\end{array}$ \\
\hline
\end{tabular}

A hallgatóság és a műfaj jellegzetességei miatt ezek a premisszák nem felelnek meg a formális logika szigorú feltételeinek, ahogy persze a hétköznapi érvelés premisszái is inkább valószínüségek, s nem bizonyosságok. Észrevehető, hogy a nagy premissza mindhárom mesében egy-egy társadalmi konvención alapszik, milyen viselkedést vár el a felnőtt társadalom egy kisgyermektől. A premissza első fele pedig megmagyarázza a gyermeknek, hogy miért is érdemes betartani a konvenciót.

Tovább is lehet bontani a szillogizmust, azaz a mesék érvrendszere végeredményben egy ok-okozati viszonyra épülő poliszillogizmus. A Hiszti manó meséjében a teljes lánc így írható le: Zsófi sokszor hisztizett $\rightarrow$ Megjelent Hiszti manó, és kinevette Zsófit $\rightarrow$ Zsófinak nem tetszett a manó, s az sem, hogy kinevette $\rightarrow$ Nem hisztizett többé $\rightarrow$ Hiszti manó mérges lett emiatt, s ő kezdett hisztizni $\rightarrow$ Zsófi nevette ki a manót.

A retorikai érvelés talán legfontosabb eszköze a példa. A példa a hasonlóság érvforrásán alapul. A példa nem egy szabályra, hanem egy másik partikuláris esetre utal. A mesemondás szituációjában mindegyik mese (kitalált) példaként, azaz parabolaként müködik: mutat a mesét hallgató kisgyereknek egy hasonló esetet. Ha már elfogadott szabályra hozunk példát, azt illusztrációnak nevezhetjük. Mivel ezek a mesék valamilyen elfogadott konvenció mellett érvelnek, tekinthetők illusztrációnak.

Szintén a példa altípusa a modell és az antimodell. A modell valamilyen utánzandó viselkedést mutat be, ezért rokonítható a tekintéllyel, amely ha a szónok tekintélye, akkor az éthosz része. A gyerekeknek ezek a mesék modellt is adnak: hogyan kerülhetik el a nevetségessé válást, a veszteséget (a játékoktól, a barátoktól), illetve olyan gyerekekről hallanak, akik sikeresen kezelték a hisztit. Hiszti manó, és a mesék kezdetén a föszereplő gyerekek még az antimodell kategóriájába sorolhatók, a történetek végére azonban Zsófi, Kati és Peti egyértelmüen modell lesz: sikeresen felülkerekedtek a hisztin (vö. Perelman, 1977/2018). 
További példákat is találunk a mesékben, amelyek részei az adott mese érvrendszerének: példák a hisztis viselkedésre, az ellenállásra Hiszti manó buzdításával szemben stb.

A nem formális bizonyításban, azaz a hétköznapi érvelésben fontos szerepe van az éthosznak. Az éthosz a beszédben megjelenő én, a jellem szavakkal történő ábrázolása, bemutatása, az éthosz azzal járul hozzá a bizonyítás erejéhez, hogy megbízhatónak, hitelt érdemlőnek mutatja a beszélőt a hallgatósága előtt (Arisztotelész, 1999; Ueding, 2011. p. 35).

A mesemondás folyamatában a mesét mondó, mesétolvasó felnőtt (a szülő) és a mese narrátorának éthosza egymással összefonódva jelenik meg. A felolvasó ismeri a konkrét hallgatóságát, s hozzá igazíthatja a mesemondást, leginkább az előadásmód megválasztásával, közbevetésekkel, sőt akár a történet módosításával is (e sorok írója például sokszor a főszereplő neve helyett a saját gyermekének a nevét mondja), illetve a jóakaratát is kimutatja már a meseolvasással. A szereplőkben a mesét hallgató gyermek saját magára ismerhet, ahogy az elbeszélt események is ismerősek lehetnek a számára, ez kiválthatja az azonosulást, s ezáltal sikeresebbé teheti a(z ön)meggyőzést. Az adja a narrátor éthoszát, hogy szakértőként mutatkozik meg: érti a hallgató lelkivilágát. A mesemondó és a narrátor közös éthosza tehát a bölcsességből és a jóakaratból táplálkozik (vö. Arisztotelész, 1999).

A belső érvek harmadik típusa a pathosz, vagyis az érzelmek kiváltása. Az érzelmek felkeltésében fontos szerepe van a jelenlét megteremtésének és a stílusnak.

$\mathrm{Az}$ elemzett mesékben a legfontosabb érzelem a nevetés. Quintilianus (2009) szerint ha a szónok megnevetteti a bírót, megszünteti benne a nyomasztó érzéseket és kizökkenti az unalomból, fásultságból. A mesét hallgató gyermek (aki itt a bíró) esetében a nyomasztó érzés a dacreakciót, hisztit kiváltó frusztráció. Emellett őt is ki kell zökkenteni, csak nem az unalomból, hanem a dac önmagát gerjesztő folyamatából (a hisztiző kisgyermek kissé a Kis herceg iszákosára emlékeztet: a frusztráció miatt hisztizik, a hisztitől pedig frusztrált lesz). A nevetéstől nem áll messze a kinevetés, amely csak akkor jó eszköz a meggyőzésben, ha egy harmadik félre irányul (tulajdonképpen az antimodellre), nem a szónokra vagy a hallgatóságára. Jelen mesékben Hiszti manó az, akit ki lehet (sőt kell) nevetni. A nevetségessé tételét szolgálja a megjelenése és a viselkedése is (amelyet a rajzos illusztráció is segít), a föszereplő ki is neveti.

További meggyőzést szolgáló érzelmek a szomorúság, a szánalom és a félelem is. A mesehallgató gyermek szánalmat érezhet a csupasz kislány iránt, akivel nem játszik senki, és Peti iránt is, akit elhagytak a játékai. Ezek a példák az attól való félelmet is felkelthetik benne, hogy ő is így járhat. A félelemkeltés persze csak akkor hatásos, ha a hallgató képes a félelem tárgya ellen tenni valamit. A mesék ezt a megoldást is felkínálják: fel kell öltözni, illetve a helyükre kell tenni a játékokat.

Perelman (1977/2018) érveléselméletének egyik fontos újdonsága, amit a fogalmak disszociációjáról mond. A disszociatív érveléskor szétválasztjuk 
a valóság elemeit egymástól, s újrarendezzük őket, elkülönítjük a valóságot a látszattól. A látszat szerint a hisztiző kisgyermek rossz, valójában viszont nem ő a hibás a viselkedéséért, hanem Hiszti manó. Hiszti manó tehát a dacot kiváltó életkori jellemzők szimbólumává válik.

\section{Összegzés}

A retorika, amelyet a 16. századtól sokszor leszükítettek, valójában egy holisztikus tudomány, avagy müvészet. A retorika elemei mindenhol felfedezhetők, ahol emberek közötti kommunikáció zajlik. És ahol kommunikáció zajlik, ott mindenképpen jele van a meggyőzés is. A nevelés pedig nagyrészt meggyőzés, hiszen az általunk elfogadott értékek hasznosságáról szeretnénk meggyőzni a gyermekeket. A nevelésben (= meggyőzésben) fontos szerepet tölt be az irodalom (amely maga is érték), kisgyermekek esetében különösen a mese.

A Hisztimesék amellett, hogy gyönyörködtetnek, nevelnek is. A Hisztimesékben olvasható három történet nem más, mint egy-egy összetett érv a szülők által közvetített társadalmi konvenciók mellett.

\section{Irodalom}

A. Jászó, A. (2012). A retorikai elemzésről. In Markó, A. (Ed.), Beszédtudomány. Az anyanyelv-elsajátítástól a zöngekezdési időig (pp. 171-191). ELTE Bölcsészettudományi Kar, MTA Nyelvtudományi Intézet.

Adamik, T., A. Jászó, A. \& Aczél, P. (2004). Retorika. Osiris Kiadó.

Adamikné Jászó, A. (2009). Retorikai gondolkodás és szövegértő olvasás I-II. Anyanyelv-pedagógia, 2(3/4), http://www.anyanyelv-pedagogia.hu/cikkek. php?id=185; http://www.anyanyelv-pedagogia.hu/cikkek.php?id=221

Adamikné Jászó, A. (2013). Klasszikus magyar retorika. Argumentáció és stílus. Holnap Kiadó.

Arisztotelész (1999). Rétorika. Telosz Kiadó.

Barthes, R. (1997). A régi retorika. In Thomka B. (Ed.), Az irodalom elméletei III. (pp. 69-178). Jelenkor Kiadó.

Bitzer, L. F. (1968). The Rhetorical Situation. Philosophy and Rhetoric, 1(1), 1-14.

Burke, K. (1968). Counter-statement. University of California Press

Burke, K. (1966). Rhetoric and Poetics. In Burke, K. Language as Symbolic Action. Essays on Life, Literature, and Method. University of California Press. https://doi. org/10.1525/9780520340664-020

Cooper, M. (1989). Analyzing Public Discourse. Waveland Press.

Corbett, E. P. J. \& Connors, R. R. J. (1999). Classical Rhetoric for the Modern Student. Oxford University Press. 
Corbett, E. P. J. (Ed., 1969). Rhetorical analyses of literary works. Oxford University Press.

Cornificius (2001). A szónoki mesterség. A C. Herenniusnak ajánlott retorika (Ret. Her.). Magyar Könyvklub.

Deliága, É. \& Lovász, H. (2017). Mit kezdjünk az akaratossággal? Pszichológiai útmutató + dacszeliditő mesék. Kulcslyuk Kiadó.

Ehninger, D. (1968). On Systems of Rhetoric. Philosophy and Rhetoric, 1(1), 131-144.

Erikson, E. H. (1997). Az emberi életciklus. In Bernáth, L. \& Solymosi, K. (Eds.), Fejlödéslélektan olvasókönyv (pp. 27-42). Tertia Kiadó.

Fazakas, I. M. (2014). A dackorszak és a hiszti. Magiszter, 12(3), 61-66. https://doi. org/10.1365/s35128-014-0788-6

Kádár, A. (2013). Az érzelmi intelligencia fejlesztése mesékkel. Magiszter 11(1). 55-66. http://rmpsz.ro/uploaded/tiny/files/magiszter/2013/tavasz/9.pdf

Kádár, A. (2014). Mesepszichológia 2. - Útravaló kényes nevelési helyzetekhez. Kulcslyuk Kiadó.

Knape, J. (2000). Allgemeine Rhetorik. Stationen der Theoriegesichte. Philipp Reclam jun. GmbH \& Co.

Lózsi, T. (2012). A mosógépszerelő érvei - a reklám retorikai elemzése. In Raátz, J. \& Tóthfalussy, Zs. (Eds.), A retorikai elemzés (pp. 27-39). ELTE BTK.

Lózsi, T. (2020). Mesebeszéd. A mese retorikai elemzése. In Lózsi, T. \& Pölcz, Á. (Eds.), Disciplina in fabula - Közelitések a meséhez (pp. 91-104). ELTE Eötvös Kiadó.

Mérei, F. \& V. Binét, Á. (1997). Gyermeklélektan. Gondolat-Medicina.

Perelman, Ch. (2018). A retorika birodalma. Retorika és érvelés. Tinta Könyvkiadó.

Platón (2005). Phaidrosz (Platónösszes művei kommentárokkal). Atlantisz Könyvkiadó.

Plett, H. (1988). Retorika és stilisztika. In Kanyó, Z. \& Síklaki, I. (Eds.), Tanulmányok az irodalomtudomány köréből (pp. 131-167). Tankönyvkiadó.

Plett, H. (2000). Systematische Rhetorik. Wilhem Fink Verlag.

Plett, H. (2001). Einführung in die rhetorische Textanalyse. Helmut Buske Verlag.

Pölcz, Á. (2020). Retorika minden tárgyban. Magyaróra, 2(1-2), 6-14.

Quintilianus, M. F. (2009). Szónoklattan. Kalligram Kiadó.

Tóth, M. Zs. (2020). Amikor Petőfi a húrok közé szorul. Magyaróra, 2(1-2), 85-94.

Vida, Á. (2011). Babapszichológia. Lélek, viselkedés, fejlödés kétéves korig. Kulcslyuk Kiadó.

Wacha, I. (2000). A retorika kompetenciái. In A. Jászó, A. \& L. Aczél, P. (Eds.), A régi új retorika (pp. 53-88). Trezor Kiadó. 


\section{Lózsi, T.}

\section{Hysteria-rhetoric}

The study contains rhetorical analyses of three tales focusing on persuasion from Judit Berg's book Hisztimesék / Hysteria tales/ (2005). The main question posed by the research is: What kind of rhetorical devices and techniques of argumentation are used in the persuasion of young children? The aim of the study is to highlight the interdisciplinarity of rhetoric with examples that can be used in everyday educational and/or pedagogical practice, and in which the methods of persuasion and techniques of argumentation are also presented (that also appear in children's literature).

Keywords: contemporary children's literature, rhetorical analysis, persuasion and argumentation techniques

Lózsi Tamás: https://orcid.org/0000-0002-0773-5283 